\title{
Becoming fat
}

\author{
Mitchell A. Lazar ${ }^{1}$ \\ Division of Endocrinology, Diabetes, and Metabolism, Departments of Medicine and Genetics, and The Penn Diabetes \\ Center, University of Pennsylvania School of Medicine, Philadelphia, Pennsylvania 19104, USA
}

Most people do not wish to become fat, for cosmetic as well as medical reasons. Despite this, there is an international epidemic of obesity fueled by sedentary lifestyles and high caloric consumption among people living in industrialized societies. Obesity is characterized by excess adipose tissue, and rational intervention requires an understanding of adipocyte genes, development, and function. The peroxisome proliferator activated receptor $\gamma(\operatorname{PPAR} \gamma)$, a member of the large family of nuclear hormone receptors, has received enormous attention as its role has emerged in the formation of adipose tissue, as well in the pathogenesis and treatment of diabetes, cardiovascular disease, and cancer (Kersten et al. 2000). In this issue of Genes \& Development, Rosen et al. (2002) and Ren et al. (2002) provide answers to two fundamental questions regarding the role of PPAR $\gamma$ in the making of a fat cell.

Shortly after its initial description as an orphan receptor related to PPAR $\alpha$ (Chen et al. 1993; Kliewer et al. 1994), PPAR $\gamma$ was found to be particularly abundant in adipose tissue and induced during adipocyte differentiation (Chawla et al. 1994; Tontonoz et al. 1994a). PPAR $\gamma$ has since been shown to be sufficient (Tontonoz et al. 1994b) as well as necessary (Barak et al. 1999; Rosen et al. 1999/ for adipocyte differentiation. A variety of adipocyte genes are transcriptional targets of PPAR $\gamma$ (Auwerx 1999). PPAR $\gamma$ ligands, most notably the thiazolidinedione (TZD) class, ameliorate insulin resistance and represent exciting new therapies for type 2 diabetes. This effect of TZDs is likely to be multifactorial, including numerous effects on adipocyte gene expression that lead to altered secretion of adipocyte proteins and fatty acids (Olefsky and Saltiel 2000).

In addition to PPAR $\gamma$, the bZip-containing C/EBP transcription factors have established roles in adipogenesis (Loftus and Lane 1997). C/EBP $\beta$ and C/EBPS are transiently increased early in adipogenesis (Cao et al. 1991). When constitutively expressed, these factors are sufficient to induce adipocyte differentiation (Yeh et al. 1995), in part owing to induction of PPAR $\gamma$ (Wu et al. 1995; Schwarz et al. 1997). C/EBP $\alpha$ is induced later. Like PPAR $\gamma$, expression of $\mathrm{C} / \mathrm{EBP} \alpha$ is sustained in the mature adipocytes (Fig. 1A; Birkenmeier et al. 1989; Christy et

${ }^{1}$ E-MAIL lazar@mail.med.upenn.edu; FAX (215) 898-5408.

Article and publication are at http://www.genesdev.org/cgi/doi/10.1101/ gad.964002. al. 1989). C/EBP $\alpha$ has been shown to be critical for adipogenesis (Freytag et al. 1994; Lin and Lane 1994), and $\mathrm{C} / \mathrm{EBP} \alpha$ and PPAR $\gamma$ positively regulate each other's expression (Shao and Lazar 1997; Hamm et al. 1999). However, previous studies have shown that PPAR $\gamma$ can induce adipogenesis in the absence of $\mathrm{C} / \mathrm{EBP} \alpha$ (Fig. 1B; Hamm et al. 1999; Wu et al. 1999).

Until now it was unknown whether $\mathrm{C} / \mathrm{EBP} \alpha$ could induce adipogenesis in the absence of PPAR $\gamma$. This is the fundamental question addressed by Rosen et al. (2002), who mutated the PPAR $\gamma$ gene in mouse embryonic stem cells, which were used to generate embryonic fibroblasts (MEFs) incapable of expressing PPAR $\gamma$. Normal MEFs can be induced to differentiate into adipocytes, and the PPAR $\gamma$ null cells allowed Rosen and colleagues to spotlight the role of PPAR $\gamma$ in the hierarchy of adipogenic transcription factors. Their study shows that ectopic expression of $\mathrm{C} / \mathrm{EBP} \alpha$ could not rescue the failure of PPAR $\gamma$ null MEFs to differentiate into adipocytes (Fig. 1C). Therefore, rather than being an equal codirector of the adipocyte differentiation program, $\operatorname{PPAR} \gamma$ has a leading role in the adipogenic hierarchy. $\mathrm{C} / \mathrm{EBP} \alpha$ undoubtedly plays a supporting role in maintaining specific aspects of the adipocyte phenotype, including insulin sensitivity (Hamm et al. 1999; Wu et al. 1999) and lipid accumulation (Wang et al. 1995). The dominance of PPAR $\gamma$ also sheds light on the mechanism of lipoatrophy in mice expressing a dominant-negative bZip polypeptide from an adipocyte-specific promoter (Moitra et al. 1998). In this setting, loss of function of all C/EBP proteins most likely interferes with adipocyte differentiation by blocking the induction of PPAR $\gamma$.

There are two main isoforms of PPAR $\gamma$ : PPAR $\gamma 1$ and PPAR $\gamma 2$ (Fig. 2A). These are generated from a single gene by differential promoter usage. PPAR $\gamma 1$ protein is the translation product of $P P A R \gamma 1$ and $P P A R \gamma 3$ mRNAs, which differ only in their 5' untranslated regions (Fajas et al. 1998). A distinct mRNA encodes PPAR 2 (Tontonoz et al. 1994a). PPAR $\gamma 2$ contains an additional 31 amino acids at its amino terminus, after which it is completely identical to PPAR $\gamma 1$. The amino terminus of PPAR $\gamma$ functions as a ligand-independent transcriptional activation domain (Adams et al. 1997). The activation function of the extended amino terminus of PPAR $\gamma 2$ is somewhat more potent than that of PPAR $\gamma 1$, and its activity is affected by insulin (Werman et al. 1997). An amino-terminal serine that is phosphorylated by MAP 
A

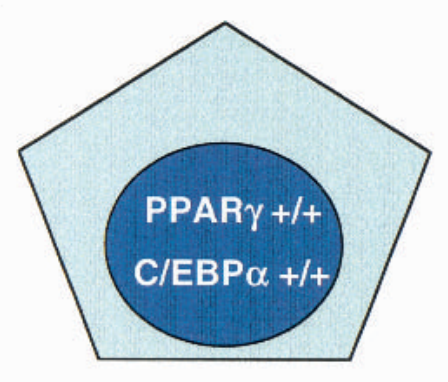

B

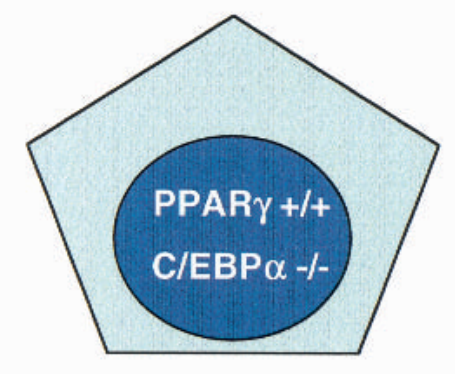

C

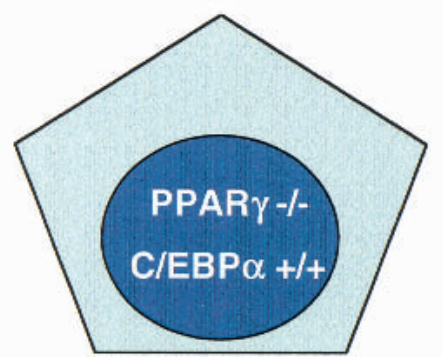

Adipogenic $\stackrel{\text { Conditions }}{\longrightarrow}$

\section{Adipogenic Conditions Ectopic PPAR $\gamma$}
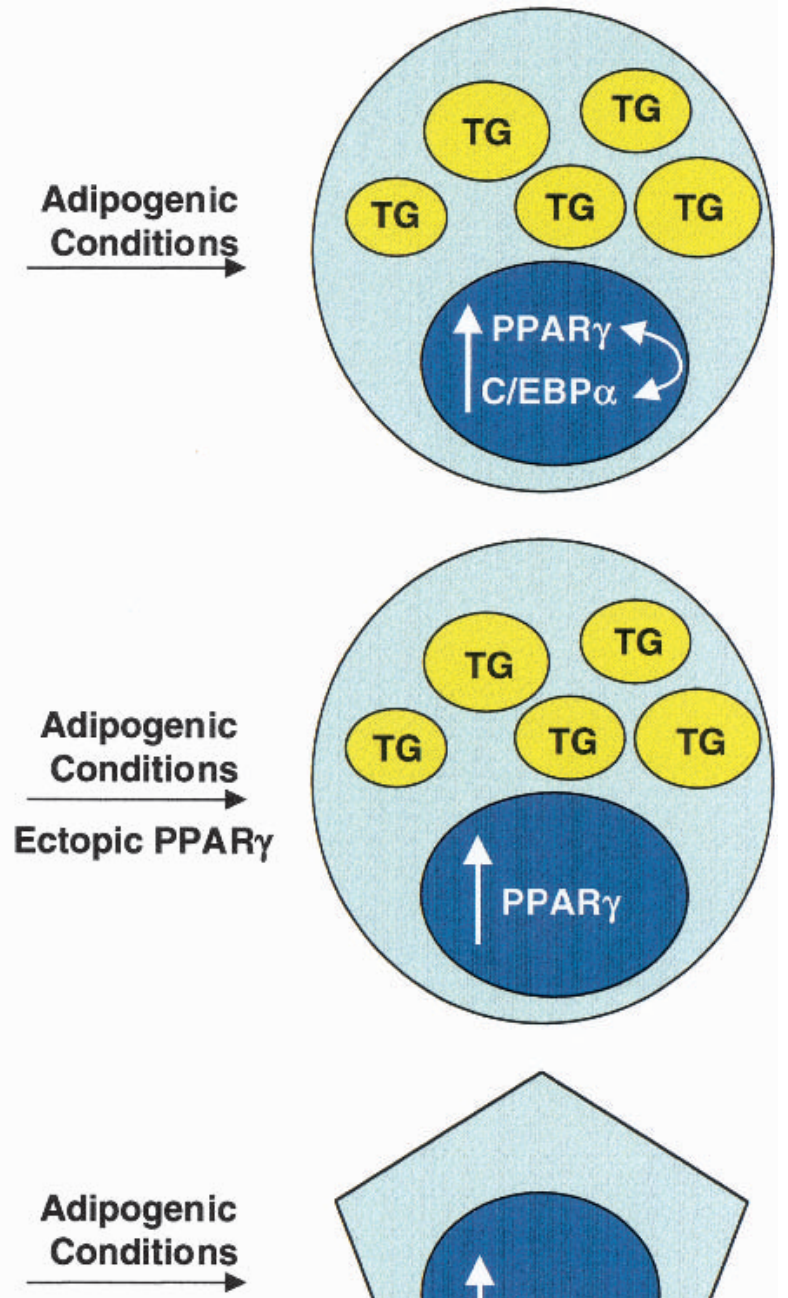

Ectopic C/EBP $\alpha$

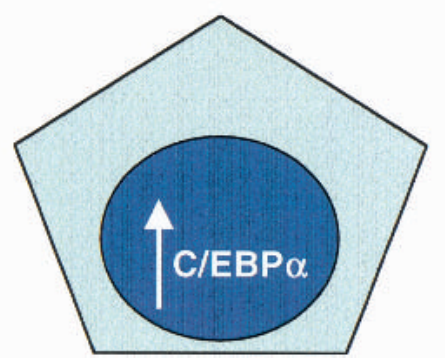

Figure 1. Role of PPAR $\gamma$ and $\mathrm{C} / \mathrm{EBP} \alpha$ in adipogenesis. (A) PPAR $\gamma$ and $\mathrm{C} / \mathrm{EBP} \alpha$ are both induced during normal adipogenesis. (B) Expression of PPAR $\gamma$ overcomes the absence of C/EBP $\alpha$. (C) Expression of C/EBP $\alpha$ fails to overcome the absence of PPAR $\gamma$. (TG) Fat stored as triglycerides.

kinase and negatively regulates PPAR $\gamma$ activity (residue 112 in mouse PPAR $\gamma 2$ ) is present in both PPAR $\gamma 1$ and PPAR 2 (Hu et al. 1996; Adams et al. 1997; Shao et al. 1998). Other properties of PPAR $\gamma 1$ and PPAR $\gamma 2$, including DNA binding, ligand binding, and interaction with coactivators, are mediated by identical domains and are also quite similar (Fig. 2A).

In addition to adipocytes, PPAR $\gamma$ is expressed in other cell types, most abundantly in macrophages and colonocytes. PPAR $\gamma 1$ is the isoform expressed in extra-adipose tissues, whereas PPAR $\gamma 2$ expression is adipocyte-specific. In macrophages, PPAR $\gamma$ ligands inhibit cytokine gene expression (Jiang et al. 1998; Ricote et al. 1998) and induce the expression of another nuclear receptor, LXR, that enhances the expression of $\mathrm{ABC}$ reverse cholesterol transporters (Repa et al. 2000; Chawla et al. 2001b; Chinetti et al. 2001). Together these effects are antiatherosclerotic, as empirically shown in rodents (Li et al. 2000) and humans (Minamikawa et al. 1998). In colonocytes, activation of PPAR $\gamma$ has been suggested to increase proliferation in the min mouse model of intestinal neoplasia (Lefebvre et al. 1998; Saez et al. 1998) yet to be antiproliferative in other colon cancer models (Brockman et al. 1998; Sarraf et al. 1998). Ligands for PPAR $\gamma$ also have beneficial effects in inflammatory bowel disease ( $\mathrm{Su}$ et al. 1999; Desreumaux et al. 2001). Although some of the anti-inflammatory effects of TZD ligands may be PPAR $\gamma$-independent (Chawla et al. 2001a), PPAR $\gamma$-dependent effects on nonadipose tissues are almost certainly mediated by PPAR $\gamma 1$ because that is the predominant isoform. In contrast, the relative importance of the two PPAR $\gamma$ isoforms for adipogenesis has remained an open question because PPAR $\gamma 1$ and PPAR $\gamma 2$ are expressed at comparable levels in adipocytes.

Ren and coworkers (2002) have elegantly addressed this question. First, PPAR $\gamma$ expression was eliminated in 
A mPPAR $\gamma 1$

\section{1}

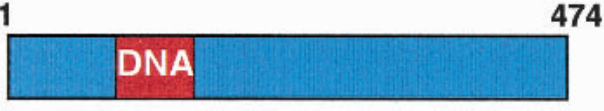

474

Adipose, macrophage, colon, other
B

Tissue Expression

505

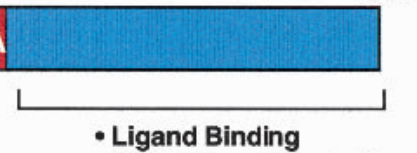

- RXR Heterodimerization

- Repression

- Ligand-dependent activation

(Ser 112 in PPAR 2 )

(Pro12 in PPARY2)

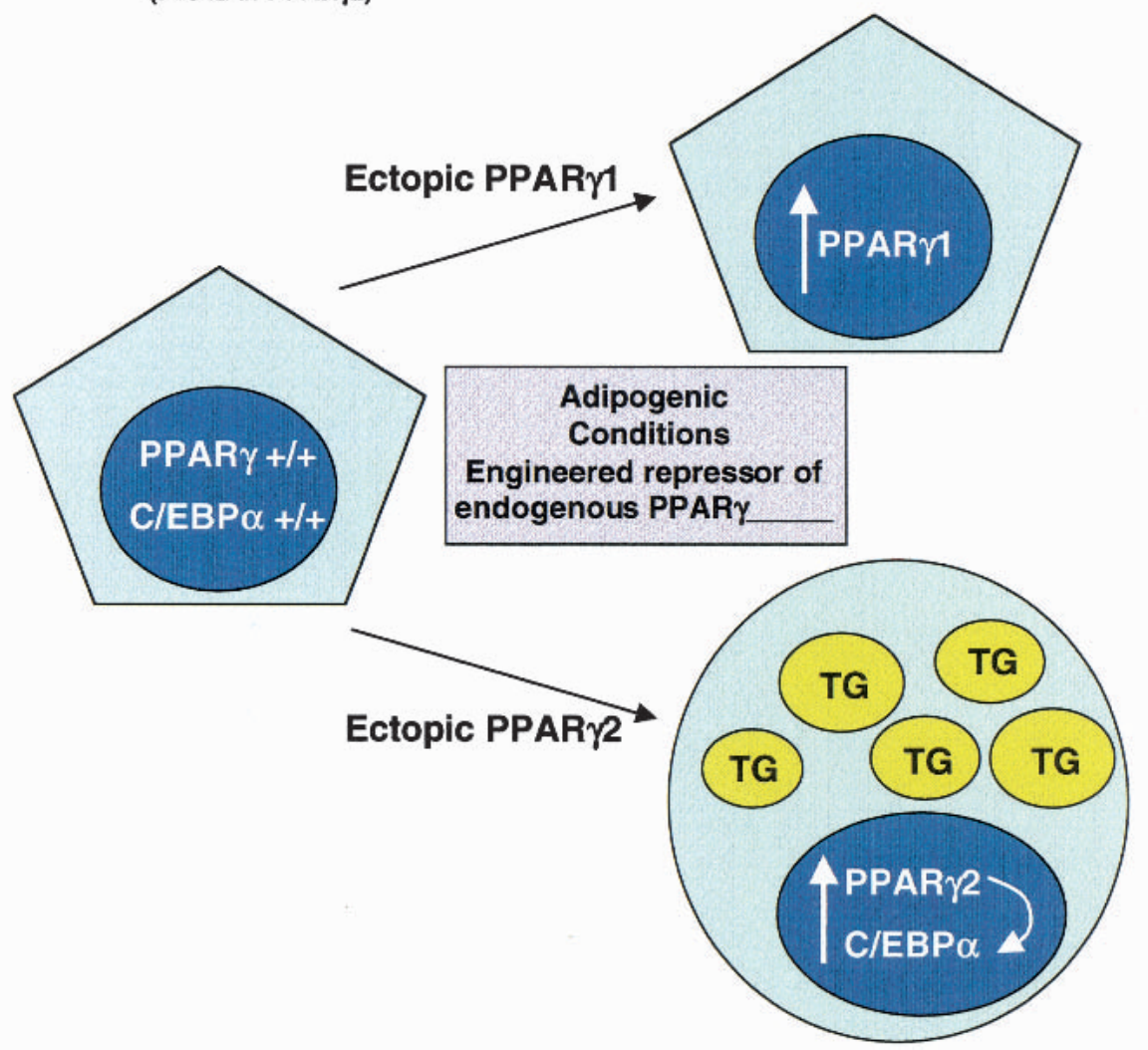

Figure 2. Role of PPAR $\gamma 2$ in adipogenesis. (A) PPAR $\gamma$ isoforms. Mouse PPAR $\gamma 1$ and PPAR $\gamma 2$ are shown. (DNA) DNA-binding domain. (B) Adipogenesis is induced by ectopic PPAR $\gamma 2$ but not PPAR $\gamma 1$ in cells whose endogenous PPAR $\gamma$ gene expression is repressed.

mouse 3T3-L1 preadipocytes, a classic model for studying adipogeneis, using a novel strategy. Transcriptional repressors were engineered to bind specifically to the PPAR $\gamma$ gene via novel zinc fingers, and inhibit PPAR $\gamma$ gene expression via a potent KRAB repression domain. Lack of PPAR $\gamma$ was established and found to prevent adipocyte differentiation, confirming previous work in PPAR $\gamma$ null models (Barak et al. 1999; Rosen et al. 1999). Ren and coworkers then used retroviruses to restore expression of either PPAR $\gamma 1$ or PPAR $\gamma 2$. Although both proteins could be expressed at comparable levels, only PPAR $\gamma 2$ was able to rescue the adipogenic phenotype (Fig. 2B). This experiment conclusively shows that PPAR $\gamma 2$ is uniquely suited for adipogenesis.
This result at first seems inconsistent with previous studies suggesting that the amino terminus of PPAR $\gamma$ is unnecessary for adipogenesis (Tontonoz et al. 1994b; Shao et al. 1998). However, those studies involved ectopic expression of wild-type and mutant PPAR $\gamma$ in cells that, unlike those used by Ren et al., could express PPAR 2 from the endogenous gene. Because PPAR $\gamma$ positively regulates its own expression, it is very possible that induction of endogenous PPAR $\gamma 2$ by ectopic PPAR $\gamma 1$ might reconcile the earlier studies with the present result. It would actually be quite interesting and important to confirm the divergent adipogenic functions of PPAR $\gamma 1$ and PPAR $\gamma 2$ in the PPAR $\gamma$ null MEFs used by Rosen et al. (2002), because endogenous PPAR $\gamma 2$ could 
not be generated after PPAR $\gamma 1$ expression in this model system.

A positive feedback role for PPAR $\gamma 1$ on PPAR $\gamma 2$ might be an important function of endogenous PPAR $\gamma 1$, whose protein levels are actually higher than those of PPAR $\gamma 2$ in adipocytes (Xue et al. 1996). This would be analogous to the role of $\mathrm{C} / \mathrm{EBP} \alpha$ in up-regulating PPAR $\gamma$ expression during normal adipogenesis. The model of PPAR $\gamma$ gene expression knockout developed by Rosen et al. (2002) could also be used to confirm the dominance of C/EBP $\alpha$ over PPAR $\gamma$ in adipose conversion of 3T3-L1 cells, the system in which the importance of $\mathrm{C} / \mathrm{EBP} \alpha$ in adipocyte differentiation has been most rigorously evaluated.

The dramatic difference in adipogenic potential of PPAR $\gamma 1$ and PPAR $\gamma 2$ is surprising, given their highly similar properties when studied in vitro. However, there are other examples of transcription factors whose biologically relevant functional domains were not predictable from molecular studies. For example, the transactivation domain of the GATA-1 transcription is dispensable for erythropoiesis, whereas another domain is critical (Weiss et al. 1997). C/EBP $\alpha$ itself has cellular functions that are independent of DNA binding (McKnight 2001). The unique role of PPAR $\gamma$ in adipogenesis is particularly interesting in light of the observation that a common human genetic variation in PPAR $\gamma$ affecting only PPAR $\gamma 2$ (the Pro12Ala mutation) provides protection from insulin resistance (Deeb et al. 1998; Altshuler et al. 2000). This variation has very modest effects on the measurable in vitro functions of the PPAR $\gamma 2$ protein (Deeb et al. 1998).

Together, these new findings move the field forward by illuminating the role of the $\gamma 2$ isoform of PPAR $\gamma$ as a critical regulator of adipogenesis. PPAR $\gamma 1$ and C/EBP $\alpha$ proteins are induced during adipogenesis and are highly expressed in mature adipocytes, where $\mathrm{C} / \mathrm{EBP} \alpha$ and probably PPAR $\gamma 1$ play important functional roles. However, PPAR $\gamma 2$ would seem to be the preferred target for treatments aimed at stopping a cell, and ultimately a person, from becoming fat.

\section{Acknowledgments}

I thank Shamina Rangwala and Claire Steppan for critical reading of the manuscript.

\section{References}

Adams, M., Reginato, M.J., Shao, D., Lazar, M.A., and Chatterjee, V.K. 1997. Transcriptional activation by PPAR $\gamma$ is inhibited by phosphorylation at a consensus mitogen-activated protein kinase site. J. Biol. Chem. 272: 5128-5132.

Altshuler, D., Hirschhorn, J.N., Klannemark, M., Lindgren, C.M., Vohl, M.C., Nemesh, J., Lane, C.R., Schaffner, S.F., Bolk, S., Brewer, C., et al. 2000. The common PPARy Pro12Ala polymorphism is associated with decreased risk of type 2 diabetes. Nat. Genet. 26: 76-80.

Auwerx, J. 1999. PPAR $\gamma$, the ultimate thrifty gene. Diabetologia 42: 1033-1049.

Barak, Y., Nelson, M.C., Ong, E.S., Jones, Y.Z., Ruiz-Lozano, P.,
Chien, K.R., Koder, A., and Evans, R.M. 1999. PPAR $\gamma$ is required for placental, cardiac, and adipose tissue development. Mol. Cell 4: 585-595.

Birkenmeier, E.H., Gwynn, B., Howard, S., Jerry, J., Gordon, J.I., Landschulz, W.H., and McKnight, S.L. 1989. Tissue-specific expression, developmental regulation, and genetic mapping of the gene encoding CCAAT/enhancer binding protein. Genes \& Dev. 3: 1146-1156.

Brockman, J.A., Gupta, R.A., and DuBois, R.N. 1998. Activation of PPAR $\gamma$ leads to inhibition of anchorage independent growth of human colorectal cancer cells. Gastroenterology 115: 1049-1055.

Cao, Z., Umek, R.M., and McKnight, S.L. 1991. Regulated expression of three C/EBP isoforms during adipose conversion of 3T3-L1 cells. Genes \& Dev. 5: 1538-1552.

Chawla, A., Schwarz, E.J., Dimaculangan, D.D., and Lazar, M.A. 1994. Peroxisome proliferator-activated receptor $\gamma(\operatorname{PPAR} \gamma)$ : Adipose predominant expression and induction early in adipocyte differentiation. Endocrinology 135: 798-800.

Chawla, A., Barak, Y., Nagy, L., Liao, D., Tontonoz, P., and Evans, R.M. 2001a. PPAR- $\gamma$ dependent and independent effects on macrophage-gene expression in lipid metabolism and inflammation. Nat. Med. 7: 48-52.

Chawla, A., Boisvert, W.A., Lee, C.-H., Laffitte, B.A., Barak, Y., Joseph, S.B., Liao, D., Nagy, L., Edwards, P.A., Curtiss, L.K., et al. 2001b. A PPAR $\gamma$-LXR-ABCA1 pathway in macrophages is involved in cholesterol efflux and atherogenesis. Mol. Cell 7: 161-171.

Chen, F., Law, S.W., and O'Malley, B.W. 1993. Identification of two MPPAR related receptors and evidence for the existence of five subfamily members. Biochem. Biophys. Res. Commun. 196: 671-677.

Chinetti, G., Lestavel, S., Bocher, V., Remaley, A.T., Neve, B., Torra, I.P., Teissier, E., Minnich, A., Jaye, M., Duverger, N., et al. 2001. PPAR $\alpha$ and PPAR $\gamma$ activators induce cholesterol removal from human macrophage foam cells through stimulation of the ABCA1 pathway. Nat. Med. 7: 53-58.

Christy, R.J., Yang, V.W., Ntambi, J.M., Geiman, D.E., Landschulz, W.H., Friedman, A.D., Nakabeppu, Y., Kelly, T.J., and Lane, M.D. 1989. Differentiation-induced gene expression in 3T3-L1 preadipocytes: CCAAT/enhancer binding protein interacts with and activates the promoters of two adipocytespecific genes. Genes \& Dev. 3: 1323-1335.

Deeb, S.S., Fajas, L., Nemoto, M., Pihlajamaki, J., Mykkanen, L., Kuusisto, J., Laakso, M., Fujimoto, W., and Auwerx, J. 1998. A Pro12Ala substitution in PPAR $\gamma 2$ associated with decreased receptor activity, lower body mass index and improved insulin sensitivity. Nat. Genet. 20: 284-287.

Desreumaux, P., Dubuquoy, L., Nutten, S., Peuchmaur, M., Englaro, W., Schoonjans, K., Desvergne, B., Wahli, W., Chambon, P., Leibowitz, M.D., et al. 2001. Attenuation of colon inflammation through activators of the retinoid $\mathrm{X}$ receptor $(\mathrm{RXR}) /$ peroxisome proliferator-activated receptor $\gamma$ heterodimer. A basis for new therapeutic strategies. I. Exp. Med. 193: $827-838$.

Fajas, L., Fruchart, J.C., and Auwerx, J. 1998. PPAR $\gamma 3$ mRNA: A distinct PPAR $\gamma$ mRNA subtype transcribed from an independent promoter. FEBS Lett. 438: 55-60.

Freytag, S.O., Paielli, D.L., and Gilbert, J.D. 1994. Ectopic expression of the CCAAT/enhancer binding protein $\alpha$ promotes the adipogenic program in a variety of mouse fibroblastic cells. Genes \& Dev. 8: 1654-1663.

Hamm, J.K., el Jack, A.K., Pilch, P.F., and Farmer, S.R. 1999. Role of PPAR $\gamma$ in regulating adipocyte differentiation and insulin-responsive glucose uptake. Ann. NY Acad. Sci. 892: $134-145$. 
Hu, E., Kim, J.B., Sarraf, P., and Spiegelman, B.M. 1996. Inhibition of adipogenesis through MAP kinase-mediated phosphorylation of PPAR $\gamma$. Science 274: 2100-2103.

Jiang, C., Ting, A.T., and Seed, B. 1998. PPAR- $\gamma$ agonists inhibit production of monocyte inflammatory cytokines. Nature 391: 82-86.

Kersten, S., Desvergne, B., and Wahli, W. 2000. Roles of PPARs in health and disease. Nature 405: 421-424.

Kliewer, S.A., Forman, B.M., Blumberg, B., Ong, E.S., Borgmeyer, U., Mangelsdorf, D.J., Umesono, K., and Evans, R.M. 1994. Differential expression and activation of a family of murine peroxisome proliferator-activated receptors. Proc. Nat1. Acad. Sci. 91: 7355-7359.

Lefebvre, A.M., Chen, I., Desreumaux, P., Najib, J., Furehart, J.-C., Geboes, K., Briggs, M., Heyman, R., and Auwerx, J. 1998. Activation of the peroxisome proliferator activated receptor $\gamma$ promotes the development of colon tumors in C57BL/6J-APCmin/+ mice. Nat. Med. 4: 1053-1057.

Li, A.C., Brown, K.K., Silvestre, M.J., Willson, T.M., Palinski, W., and Glass, C.K. 2000. Peroxisome proliferator-activated receptor $\gamma$ ligands inhibit development of atherosclerosis in LDL receptor-deficient mice. J. Clin. Invest. 106: 523-531.

Lin, F.-T. and Lane, M.D. 1994. CCAAT/enhancer binding protein $\alpha$ is sufficient to initiate the 3T3-L1 adipocyte differentiation program. Proc. Natl. Acad. Sci. 91: 8757-8761.

Loftus, T.M. and Lane, M.D. 1997. Modulating the transcriptional control of adipogenesis. Curr. Opin. Genet. Dev. 7: 603-608.

McKnight, S.L. 2001. McBindall-A better name for CCAAT/ enhancer binding proteins? Cell 107: 259-261.

Minamikawa, J., Tanaka, S., Yamauchi, M., Inoue, D., and Koshiyama, H. 1998. Potent inhibitory effect of troglitazone on carotid arterial wall thickness in type 2 diabetes. J. Clin. Endocrinol. Metab. 83: 1818-1820.

Moitra, J., Mason, M.M., Olive, M., Krylov, D., Gavrilova, O., Marcus-Samuels, B., Feigenbaum, L., Lee, E., Aoyama, T., Eckhaus, M., et al. 1998. Life without fat: A transgenic mouse. Genes \& Dev. 12: 3168-3181.

Olefsky, J.M. and Saltiel, A.R. 2000. PPAR $\gamma$ and the treatment of insulin resistance. Trends Endocrinol. Metab. 11:362368.

Ren, D., Collingwood, T.N., Rebar, E.J., Wolffe, A.P., and Camp, H.S. 2002. PPAR $\gamma$ knockdown by engineered transcription factors: Exogenous PPAR $\gamma 2$ but not PPAR $\gamma 1$ reactivates adipogenesis. Genes \& Dev. 16: 27-32 (this issue).

Repa, J.J., Turley, S.D., Lobaccaro, J.A., Medina, J., Li, L., Lustig, K., Shan, B., Heyman, R.A., Dietschy, J.M., and Mangelsdorf, D.J. 2000. Regulation of absorption and ABC1-mediated efflux of cholesterol by RXR heterodimers. Science 289: 1524 1529.

Ricote, M., Li, A.C., Willson, T.M., Kelly, C.J., and Glass, C.K. 1998. The peroxisome proliferator-activated receptor- $\gamma$ is a negative regulator of macrophage activation. Nature 391: $79-82$.

Rosen, E.D., Sarraf, P., Troy, A.E., Bradwin, G., Moore, K., Milstone, D.S., Spiegelman, B.M., and Mortensen, R.M. 1999. PPAR $\gamma$ is required for the differentiation of adipose tissue in vivo and in vitro. Mol. Cell 4: 611-617.

Rosen, E.D., Hsu, C.-H., Wang, X., Sakai, S., Freeman, M.W., Gonzalez, F.J., and Spiegelman, B.M. 2002. C/EBP $\alpha$ induces adipogenesis through PPAR $\gamma$ : A unified pathway. Genes \& Dev. 16: 22-26 (this issue).

Saez, E., Tontonoz, P., Nelson, M.C., Alvarez, J.G., Ming, U.T., Baird, S.M., Thomazy, V.A., and Evans, R.M. 1998. Activators of the nuclear receptor PPAR $\gamma$ enhance colon polyp formation. Nat. Med. 4: 1058-1061.
Sarraf, P., Mueller, E., Jones, D., King, F.J., DeAngelo, D.J., Partridge, J.B., Holder, S.A., Chen, L.B., Singer, S., Fletcher, C., et al. 1998. Differentiation and reversal of malignant changes in colon cancer through PPAR $\gamma$. Nat. Med. 4: 1046-1052.

Schwarz, E.J., Reginato, M.J., Shao, D., Krakow, S.L., and Lazar, M.A. 1997. Retinoic acid blocks adipogenesis by inhibiting C/EBP $\beta$-mediated transcription. Mol. Cell. Biol. 17: 15521561.

Shao, D. and Lazar, M.A. 1997. PPAR $\gamma$, C/EBP $\alpha$, cell cycle status and the commitment to adipocyte differentiation. J. Biol. Chem. 272: 21473-21478.

Shao, D., Rangwala, S.M., Bailey, S.T., Krakow, S.L., Reginato, M.J., and Lazar, M.A. 1998. Interdomain communication regulating PPAR $\gamma$ ligand binding. Nature 396: 377-380.

Su, C.G., Wen, X., Jiang, W., Rangwala, S.M., Keilbaugh, S.A., Flanigan, A., Murthy, S., Lazar, M.A., and Wu, G.D. 1999. A novel therapy for colitis utilizing PPAR $\gamma$ ligands to inhibit the epithelial inflammatory response. J. Clin. Invest. 104: 383-389.

Tontonoz, P., Hu, E., Graves, R.A., Budavari, A.I., and Spiegelman, B.M. 1994a. mPPAR $\gamma 2$ : Tissue-specific regulator of an adipocyte enhancer. Genes \& Dev. 8: 1224-1234.

Tontonoz, P., Hu, E., and Spiegelman, B.M. 1994b. Stimulation of adipogenesis in fibroblasts by PPAR $\gamma 2$, a lipid-activated transcription factor. Cell 79: 1147-1156.

Wang, N.D., Finegold, M.J., Bradley, A., Ou, C.N., Abdelsayed, S.V., Wilde, M.D., Taylor, L.R., Wilson, D.R., and Darlington, G.J. 1995. Impaired energy homeostasis in C/EBP $\alpha$ knockout mice. Science 269: 1108-1112.

Weiss, M.J., Yu, C., and Orkin, S.H. 1997. Erythroid-cell-specific properties of transcription factor GATA-1 revealed by phenotypic rescue of a gene-targeted cell line. Mol. Cell. Biol. 17: 1642-1651.

Werman, A., Hollenberg, A., Solanes, G., Bjorbaek, C., VidalPuig, A.J., and Flier, J.S. 1997. Ligand-independent activation domain in the $\mathrm{N}$ terminus of PPAR $\gamma$. Differential activity of PPAR $\gamma 1$ and 2 isoforms and influence of insulin. J. Biol. Chem. 272: 20230-20235.

Wu, Z., Bucher, N.L.R., and Farmer, S.R. 1995. Conditional ectopic expression of C/EBP $\beta$ in NIH-3T3 cells induces PPAR $\gamma$ and stimulates adipogenesis. Genes \& Dev. 9: 2350-2363.

Wu, Z., Rosen, E.D., Brun, R., Hauser, S., Adelmant, G., Troy, A.E., McKeon, C., Darlington, G.J., and Spiegelman, B.M. 1999. Cross-regulation of C/EBP $\alpha$ and PPAR $\gamma$ controls the transcriptional pathway of adipogenesis and insulin sensitivity. Mol. Cell 3: 151-158.

Xue, J.-C., Schwarz, E.J., Chawla, A., and Lazar, M.A. 1996. Distinct stages in adipogenesis revealed by retinoid inhibition of differentiation after induction of PPAR $\gamma$. Mol. Cell. Biol. 16: 1567-1575.

Yeh, W.-C., Cao, Z., Classon, M., and McKnight, S.L. 1995. Cascade regulation of terminal adipocyte differentiation by three members of the C/EBP family of leucine zipper proteins. Genes \& Dev. 9: 168-181. 


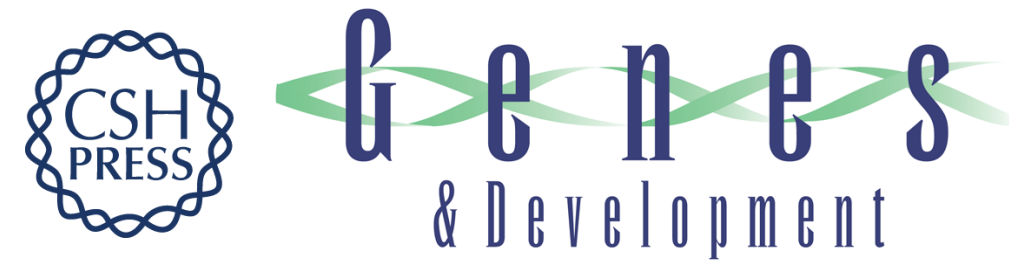

\section{Becoming fat}

Mitchell A. Lazar

Genes Dev. 2002, 16:

Access the most recent version at doi:10.1101/gad.964002

References This article cites 50 articles, 22 of which can be accessed free at: http://genesdev.cshlp.org/content/16/1/1.full.html\#ref-list-1

\section{License}

Email Alerting Receive free email alerts when new articles cite this article - sign up in the box at the top Service right corner of the article or click here.

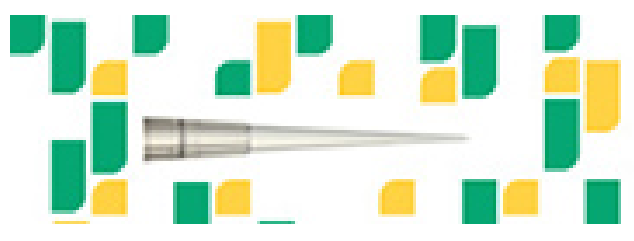

